\title{
Enterprises' External Financing and Effect of RMB Exchange through Financial Channel
}

\author{
Yanzhao Gong1, Chongrui $\mathrm{Du}^{2}$ \\ ${ }^{1}$ International Economics and Trade Department, School of Economics, Shandong University of Technology, Zibo, China \\ ${ }^{2}$ Department of Finance, School of Economics, Shandong University of Technology, Zibo, China \\ Email: yanzhaogong@163.com,873215887@qq.com
}

How to cite this paper: Gong, Y.Z. and Du, C.R. (2021) Enterprises' External Financing and Effect of RMB Exchange through Financial Channel. Open Access Library Journal, 8: e7704.

https://doi.org/10.4236/oalib.1107704

Received: June 27, 2021

Accepted: July 18, 2021

Published: July 21, 2021

Copyright $\odot 2021$ by author(s) and Open Access Library Inc.

This work is licensed under the Creative Commons Attribution International License (CC BY 4.0).

http://creativecommons.org/licenses/by/4.0/

(c) (i) Open Access

\begin{abstract}
Exchange rate is one of the important factors that affect financing decisions of enterprises. With the acceleration of China's opening up to the outside world, the transmission mechanism of the exchange rate through financial channel is more effective, and enterprises are more sensitive to exchange rate change in their decisions of external financing. Especially with the marketization of RMB exchange rate, how to avoid the adverse impact of exchange rate fluctuations is a difficult task faced by many Chinese export-oriented enterprises. This paper analyzes the spillover effect of RMB exchange rate transmitted through financial Channel and puts forward corresponding policies suggestions for Chinese enterprises.
\end{abstract}

\section{Subject Areas}

Entrepreneurship

\section{Keywords}

External Financing, Exchange Rate, Financial Channel, Spillover Effects

\section{Introduction}

The impact of exchange rate on enterprises is mainly generated through trade channels and financial channels. Specifically, the trade channel links the exchange rate fluctuations with the quantity of import and export products through the price of import and export products [1]. The financial channel affects the external financing behavior of enterprises by the exchange rate fluctuations, thus affecting the business performance of enterprises. Existing literature focus on the trade channel of exchange rate pass-through [2] [3] [4] [5]. However, with the continuous improvement of China's opening-up policy, foreign debt control has 
been relaxed [6]. In December 2008, the State Administration of Foreign Exchange (SAFE) adjusted the proportion of enterprises' export payment in advance and import deferred payment in foreign exchange from $10 \%$ to $25 \%$. In May 2013, SAFE canceled the approval process of foreign debt account opening, foreign exchange settlement and principal and interest service, simplifying the registration and management process of foreign debt. In September 2015, SAFE decided to cancel the approval of the quota of foreign debt issued by enterprises and adopted a record system. In January 2021, SAFE decided to relax the restrictions on the inflow amount of foreign exchange capital account. So the threshold for Chinese enterprises to conduct foreign currency financing has been lower. The financial channel of exchange rate pass-through has attracted more attentions.

\section{The Correlation between Chinese Enterprises' External Financing and RMB Exchange Rate}

Before the exchange rate reform in 2005, China adopted a fixed exchange rate system of pegging RMB to the US dollar, and the central parity rate between US dollar and RMB was maintained at about 8.2 for a long time, which greatly reduced hedge trading for Chinese enterprises. Due to the strict capital control policy, it is difficult for the vast majority of enterprises to conduct overseas financing. By the end of 2004, the foreign debt of Chinese enterprises was only about 10.4 billion US dollars. Therefore, enterprises could not effectively use foreign capital, and the financial channel effect of exchange rate was almost negligible.

In July 2005, China reformed RMB exchange rate mechanism and adopted a managed floating exchange rate system based on market supply and demand, with reference to a basket of currencies, in place of the previous fixed exchange rate system pegging RMB to the US dollar. The pressure of RMB appreciation against the US dollar was released, and the RMB exchange rate entered a long-term rising stage. By the end of 2008 the dollar was rising to 6.84 Yuan per dollar. At the same time, the government loosened the control of cross-border investment and financing of enterprises, which enabled Chinese enterprises to make better use of foreign capital to expand their business. By the end of 2008, the foreign currency debt of Chinese enterprises had reached 36.3 billion US dollars, and the financial channel of exchange rate pass-through was gradually highlighted.

Since 2009, RMB exchange rate has continued to appreciate, partly because of less impact from the subprime mortgage crisis. At this time, the quantitative easing policy implemented by the United States reduced the financing interest rate of the US dollar to almost zero, while China's economic growth was relatively good, which further stimulated the external financing activities of Chinese enterprises. At the end of 2013, the RMB continued to appreciate to 6.12 per US dollar. As a result, the foreign debt of Chinese enterprises kept rising, reaching 
177.4 billion US dollars at the end of the year.

After 2014, the US gradually withdrew from the quantitative easing policy, the US dollar entered a cycle of appreciation, and China began to enter a new transitional period (so called China's New Normal), when outside world held a pessimistic attitude towards China's economic prospect. The RMB exchange rate showed a depreciation trend, and the foreign currency financing costs of Chinese enterprises continued to rise and their economic activities were also affected to some extent.

In August 2015, the RMB exchange rate formation mechanism ushered in the second major reform. The RMB exchange rate is to be set by a central parity rate approach which is based on the "previous closing rate" and the "exchange rate movements of a basket of currencies". This improvement of RMB exchange rate formation has further intensified the two-way fluctuations of the RMB exchange rate against the US dollar. From 2015 to the end of 2020, the exchange rate of RMB against the US dollar fluctuated between 6.2 and 7.07, and the financial channel of exchange rate also played an increasingly prominent role. Due to the two-way fluctuations of RMB exchange rate, the growth rate of foreign currency financing of Chinese enterprises is gradually slowing down, but the overall scale is still large. By the end of 2020, the foreign currency debt of Chinese enterprises has reached 697.4 billion US dollars (see Graph 1).

\section{The Transmission Path and Spillover Effect of Exchange Rate through Financial Channel}

From above, we can see appreciation of RMB will encourage enterprises to borrow more from abroad while depreciation will restrain business financing abroad. Currency appreciation will lighten the burden of liabilities denominated in US dollar, and this will either improve the enterprises' balance sheet or reduce the cost of refinancing from abroad. Of course, this will lower financial risk expectations on enterprises and furtherly encourage the enterprises to increase the foreign currency debt to expand domestic investments. In addition, currency appreciation will also improve the repayment ability of domestic enterprises, which not only reduces the credit default risk of enterprises, but also increases the supply of foreign currency loans for enterprises. Therefore, enterprises can more easily conduct foreign currency financing while RMB depreciation will lead to the opposite outcome.

\subsection{Balance Sheet Effect}

Since Chinese enterprises often raise foreign currency debt, they will be embarrassed by currency mismatch of assets and liabilities, that is, the local currency is used to represent the enterprise assets and the foreign currency is used to represent the enterprise liabilities. Due to the existence of such currency mismatch, when the $\mathrm{RMB}$ exchange rate changes, the net value of assets of Chinese enterprises will fluctuate therefore face potential losses. 


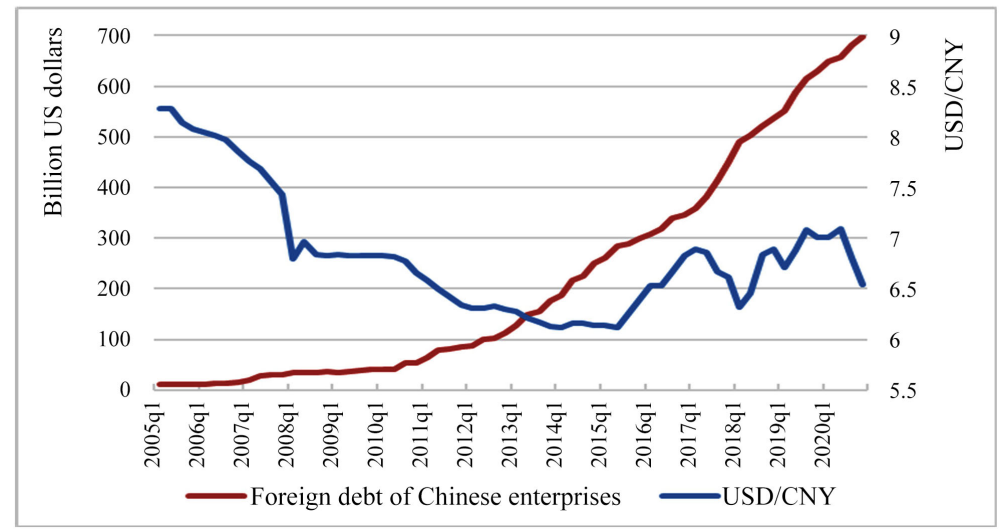

Graph 1. Foreign debt of Chinese enterprises and RMB exchange rate (Sources: Resset; BIS).

\subsection{The Inhibition and Stimulus Effect of External Refinancing}

When enterprises need foreign currency refinancing, they will issue bonds or make loans from foreign banks or other institutions. If the exchange rate changes greatly afterwards, say large appreciation of RMB relative to US dollar, their refinancing costs will be decreased accordingly, and this will motivate enterprises to borrow more from abroad, because they will repay the debt with less RMB. In other words, exchange rate appreciation will reduce enterprises' expectation of future exchange rate risks and thus reduce their refinancing costs. However, RMB depreciation will increase enterprises' expectation of future exchange rate risks and thus increase their refinancing costs and will inhibit enterprises from borrowing from foreign market.

\subsection{Capital Supply Effect}

If RMB is on an upward trend, Chinese companies will have to pay less in their own currency when their foreign debts come due, improving their ability to repay. With the enhancement of repayment ability of enterprises, the risk of credit default will be reduced [7], and relevant foreign institutions will be more inclined to extend loans to them, which will increase the supply of foreign currency loans for Chinese enterprises, so that enterprises can more easily obtain external financing, while RMB depreciation will have an opposite effect.

\subsection{Expectation Effect of Financial Risk}

When RMB continues to appreciate, companies' liabilities will decrease relative to their assets, which will reduce the leverage ratio of local companies. The leverage ratio is an important indicator to measure the financial risk of an enterprise. The reduction of leverage ratio will improve its credit standing in capital market of an enterprise, and thus reduce the expectation on its financial risk by enterprise managers. The enterprise will be more confident to bear more debts whatever in home currency or foreign currency to carry more economic activities. Devaluation does the opposite. 
Despite all above, enterprises can also take advantage of the exchange rate changes for hedging transactions. When enterprises expect RMB to appreciate, they can borrow foreign currency in order to earn the difference of exchange rate changes when the debt matures in the future. Similarly, when the enterprise expects the depreciation of RMB, the enterprise should minimize the financing in foreign currency to reduce the local currency payment at maturity.

\section{Conclusions and Policy Implications}

From the above, we can draw the following conclusion that exchange rate fluctuations do have an important impact on enterprises' external financing through financial channels. Since the reform of RMB exchange rate, the fluctuation of RMB exchange rate has an obvious correlation with the external financing of Chinese enterprises. The fact is that after the reform of RMB exchange rate formation mechanism in 2005, the continuous appreciation of RMB led to the rapid growth of corporate external debt. However, after the reform of RMB exchange rate in 2015, the two-way fluctuations of RMB exchange rate increased and the growth of corporate external debt slowed down. Exchange rate fluctuations will generate a balance sheet effect, inhibiting and stimulating effect of external refinancing, capital supply effect and financial risk expectations effect to stimulate or contract external financing of Chinese enterprises. These conclusions have many policy implications.

Firstly, fluctuation of RMB exchange rate may be destructive for enterprises with heavy debts. So, to keep a reasonable size of foreign debts may be critical for enterprises to avoid major financial loss caused by unexpected exchange rate fluctuations. Enterprises should consider internal and external conditions when financing abroad. Especially, when credit market is favorable with a lower interest rate, enterprises should resist the temptation to borrow and not blindly increase their foreign debt to avoid the potential debt crisis in the future.

Secondly, properly adjust the currency structure of foreign currency debts is also important. For a long time, Chinese enterprises prefer to take US dollar debts and become more sensitive to US dollar rate against RMB. So, enterprises should make efforts to spread their foreign debts across different currencies to disperse the impact of the single currency movements. When necessary, enterprises can refer to domestic banks for help in this aspect.

Lastly, with the progress of financial market building, many financial instruments related to foreign exchange are increasingly developed and perfected. Enterprises can learn to use these financial instruments to hedge their own assets and liability to fully cover the risks caused by exchange rate fluctuations.

On national level, to keep a reasonable size of foreign debts especially in the form of bank loan and bond issuance is very important to keep sound balance sheets of international payments, as well as to avoid systematic financial crisis. Especially when RMB exchange rate is favorable for enterprises to undertake foreign debts, some proper policies and measures should be implemented to re- 
gulate the external financing behavior of enterprises.

Needless to say, the analysis in this paper is to link the USD/RMB exchange rate with the foreign liabilities of Chinese enterprises, assuming that all the foreign debts of Chinese enterprises are in US dollars, but in fact, this is not true. Therefore, it is still worth studying whether other bilateral exchange rates of RMB and external financing of Chinese enterprises has the same correlations as expounded in this paper. In addition, the global financial crisis, COVID-19 and other special events will lead to the deterioration of the global economic environment, thus affecting the financial channel of RMB exchange rate transmission, but this paper does not deal with this, which also needs to be further studied.

\section{Conflicts of Interest}

The authors declare no conflicts of interest regarding the publication of this paper.

\section{References}

[1] Kearns, J. and Patel, N. (2016) Does the Financial Channel of Exchange Rates Offset the Trade Channel? https://www.bis.org/publ/qtrpdf/r_qt1612i.htm

[2] Dao, M.C., Minoiu, C. and Ostry, J.D. (2017) Corporate Investment and the Real Exchange Rate. IMF Working Paper No. 17/183.

https://papers.ssrn.com/sol3/papers.cfm?abstract_id=3124372 https://doi.org/10.5089/9781484313749.001

[3] Banerjee, R., Hofmann, B. and Mehrotra, A. (2020) Corporate Investment and the Exchange Rate: The Financial Channel. BIS Working Papers No. 839. https://www.bis.org/publ/work839.htm. 2020-2-4/2021-5-9

[4] Li, L. (2012) The Impact of Exchange Rate Fluctuations on Industrial Structure-An Empirical Analysis of FDI and Trade Channels. Systems Engineering, 30, 117-122.

[5] Yuan, S.G. and Zheng, W. (2015) An Empirical Analysis of the Impact of RMB Real Exchange Rate Fluctuation on the Import and Export of Export-Oriented Enterprises. International Economic and Trade Exploration, 31, 88-103.

[6] Han, J.J. and Wang, Q.C. (2019) The Development Stage and Theoretical Analysis of Foreign Currency Debt of Chinese Enterprises. New Finance, 3, 19-22.

[7] Chen, X.L. and Liu, X.Y. (2020) Financial Channel of RMB Exchange Rate PassThrough: Theoretical Analysis and Empirical Test. Financial Forum, 25, 31-43. 